\title{
Kirurgi ved medfødt øyelokksptose
}

\section{Via mindre invasive adganger til øyelokk og orbita kan behandlingen av medfødt øyelokksptose gjøres mer skånsomt for pasienten.}

Medfødt øyelokksptose er en øyelokksanomali hvor ett eller begge øyelokk står lavere enn normalt. Tilstanden skyldes nedsatt funksjon av øyelokkets løftemuskel og er til stede ved fødselen. Ptose kan forårsake utseendemessige problemer og problemer knyttet til utviklingen av normal synsfunksjon og den generelle motoriske utviklingen. Tidlig kirurgisk behandling er ofte nødvendig for å forhindre utvikling av amblyopi og feilstilling av hodet.

I mitt doktorarbeid presenteres studier på mindre invasive kirurgiske metoder for korreksjon av medfødt øyelokksptose og studier på den morfologiske anatomien i øyelokket og i orbita. For moderat ptose har vi beskrevet en teknikk for muskelreseksjon hvor septum orbitale ikke blir skadet under operasjonen. For tilfeller med uttalt medfødt ptose har vi presentert en mindre invasiv modifikasjon av Crawfords klassiske teknikk. Vi fant at begge metodene kan brukes - og med like gode resultater som de tradisjonelle teknikkene. I anatomiske studier av orbita har vi vist det anatomiske grunnlaget for en alternativ, mindre invasiv kirurgisk adgang til øvre sentrale orbita.

Ved korreksjon av medfødt øyelokkptose kan man ved å benytte mindre invasive kirurgiske adganger til øyelokk og orbita oppnå like gode resultater som med de klassiske metodene og uten at bindevev, fettvev og hud blir unødig skadet under operasjonene.

Dag Krohn-Hansen

dag.krohn-hansen@ous-hf.no

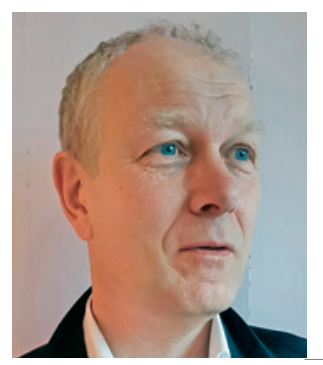

Dag Krohn-Hansen. Foto: AstridFoto

Disputas

Dag Krohn-Hansen disputerte for ph.d.-graden ved Universitetet i Oslo 8. juni 2016. Tittelen på avhandlingen er Studies on surgical techniques and surgical anatomy of the orbit for correction of congenital eyelid ptosis.

\section{Operasjonsvolum og reoperasjoner etter kneprotesekirurgi}

\author{
Sykehus med høyt volum av kneproteseoperasjoner hadde bedre resul- \\ tater og færre revisjoner enn sykehus med lavt operasjonsvolum.
}

Det opereres nå ca. 6000 kneproteser per år i Norge. Disse registreres i Nasjonalt register for leddproteser. 10-20\% av befolkningen har risiko for å utvikle kneartrose. Av disse får ca. $50 \%$ symptomatisk artrose og kan ha behov for kneprotese. Rundt $90 \%$ får totalprotese, de resterende $10 \%$ uniprotese. Det er varierende resultater etter kneproteseoperasjoner, og vi ville undersøke om noe kunne forklares med lavt versus høyt volum i sykehusene. Spesielt for uniprotesene er det lenge vist høy revisjonsrisiko sammenlignet med totalprotesene.

I mitt doktorarbeid fant vi en betydelig variasjon i sykehusenes operasjonsvolum, både for totalproteser og uniproteser. For totalprotesene fant vi at sykehus der man opererer flere enn 100 per år, hadde de beste resultatene. For uniprotesene var tallene generelt mye lavere - i 2008 var gjennomsnittsvolumet av uniproteser åtte per sykehus per år, sammenlignet med 60 totalproteser. Ved sykehus der man opererte mer enn 40 uniproteser per år, var risikoen for reoperasjon minst, sammenlignet med sykehus der det ble operert under ti per år.

Leddregisteret har på bakgrunn av våre funn oppfordret norske ortopeder til enten å øke operasjonsvolumet for uniproteser eller sende pasientene til et annet sykehus som gjør mange slike operasjoner. Dette har resultert $i$ at færre sykehus opererer uniproteser, og disse har dermed større volum. Det virker nå som om resultatene er blitt bedre i siste tidsperiode.

\section{Mona Badawy}

mona.badawy@helse-bergen.no

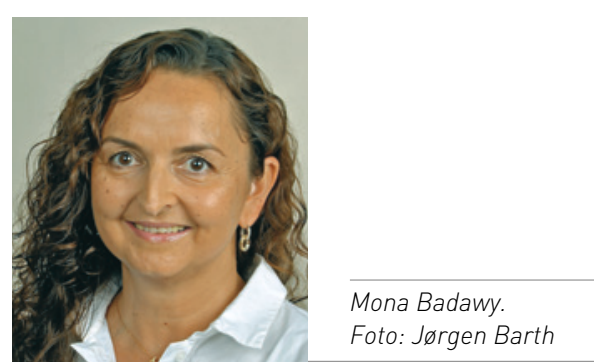

Disputas

Mona Badawy disputerte for ph.d.-graden ved Universitetet i Bergen 7.10. 2016. Tittelen på avhandlingen er Influence of hospital procedure volume on the risk of revision in knee arthroplasty surgery. 